\title{
Thermal and Dynamic Properties of Woven Kenaf/Carbon Fibre Reinforced Epoxy Hybrid Composite
}

\author{
Aisyah H.A..$^{*}$, Paridah M.T. ${ }^{*}$, Sapuan S.M. ${ }^{12}$, Khalina A. ${ }^{1,2}$, Berkalp O.B. ${ }^{3}$, Wahab M.S. ${ }^{4}$, Lee S.H..${ }^{*}$ and \\ Ramli N.1 \\ 1 Institute of Tropical Forestry and Forest Products (INTROP), Universiti Putra Malaysia, 43400 UPM \\ Serdang, Selangor, Malaysia; a.humaira.aisyahl@gmail.com (A.H.A) \\ $2 \quad$ Faculty of Engineering, Universiti Putra Malaysia, 43400 UPM Serdang, Selangor, Malaysia; \\ sapuan@upm.edu.my (S.S.M); khalina@upm.edu.my (K.A) \\ 3 Faculty of Textile Technology and Design, Istanbul Technical University, İnönü Caddesi. No: 65, \\ Gumussuyu 34437, Beyoglu Istanbul, Turkey.; berkalp@itu.edu.tr (B.O.B) \\ 4 Faculty of Mechanical Engineering, Universiti Tun Hussien Onn Malaysia (UTHM), 86400 Batu Pahat, Johor, \\ Malaysia; saidin@uthm.edu.my \\ * Correspondence: a.humaira.aisyah@gmail.com (A.H.A), parida@upm.edu.my (P.M.T), and \\ lee_seng@upm.edu.my (L.S.H); Tel.: +60-38947-1880
}

\begin{abstract}
The effects of carbon fiber hybridisation on the thermal properties of woven kenaf reinforced epoxy composites kenaf fibre were studied. Woven kenaf hybrid composites at the different weave designs of plain and satin, and fabric count of $5 \times 5$ and $6 \times 6$ were manually prepared by vacuum infusion technique. Thermal properties of pure carbon fibre and hybrid composites were conducted by using thermogravimetric analyser (TGA) and differential scanning calorimeter (DSC). It was found that at high kenaf fibre content showed better thermal stability while the highest thermally stable was found in pure carbon fibre composite. The TG and DTG results showed that the amount of residue decreased in plaindesigned hybrid composite compared to satin-designed hybrid composite. The DSC data revealed that the presence of woven kenaf increase decomposition temperature.
\end{abstract}

Keywords: hybrid composites, thermal analysis, kenaf, carbon fibre, epoxy

\section{Introduction}

Over the last decade, natural fibre is known as a reinforcement material in polymer composite, due to the environmental concerns by substituting synthetic or man-made fibres. Natural fibre reinforced polymer composite (NFRPC) is a composite material made up of a polymer matrix mixed with natural fibres, such as oil palm [1], jute [2, 3], flax [4], banana fibre [5], kenaf [6, 7] ramie [8]. These fibres are widely used as reinforcements in the NFRPC because they are low in density, good in mechanical properties, recyclable, and well in terms of strength per weight materials $[9,10]$. Furthermore, natural fibres are favoured over synthetic fibres because they are abundant, renewable, and biodegradable.

Among these fibres, kenaf (Hibiscus cannabinus) is remarkable as one of the potential natural fibres that can be used in the bio-based composite production because of its price, properties, and fast to be grown [11-13]. Kenaf bast has good prospective as a reinforcement agent for natural fibre composite because it has long fibre with good mechanical properties and high strength that can be converted to a high performance composite [14, 15]. Compared to softwood fibres, bast fibre is slightly shorter $(2.48$ to $3.60 \mathrm{~mm})$ and thinner that can increase the ability of bonding and strength development $[16,17]$. In addition, the slenderness ratio 
(fibre length/fibre diameter) of kenaf bast fibres is comparable to those of softwood fibres [18] and bast fibre have low lignin content $(14.7 \%)$ which attributed to the quality of bast fibres [16]. For the past several years, kenaf fibres have been shown to be suitable for fibre reinforced composite applications such as particleboard, medium density fibreboard (MDF), polymer matrix composite (PMC), pultruded products, non-woven materials, and woven materials.

However, the performance of the NFRPC is still not comparable with the synthetic polymeric composite. Therefore, hybridisation of synthetic fibre with natural fibres is suggested to produce biodegradable composite. Furthermore, hybridisation can overcome NFRRC disadvantages such as poor in fiber-matrix bonding adhesion [19, 20], higher water absorption and hydrophilic in nature [21, 22], lack in wettability [23,24], and low thermal properties [25]. Thus, hybridisation with synthetic fibre such as carbon fibre, glass fibre, aramic, and Kevlar is believed can improve the mechanical and thermal properties of the composites. Many researchers have been worked out to utilise natural fibre by hybridisation with synthetic fibres, such as kenaf/Kevlar [26], flax/glass fibre [27], jute/carbon fibre [28], sisal/carbon fibre [29], ramie/glass fibre [30], and flax/carbon fibres [31] composites.

Various studies have proved that the thermal properties of NFPC improved by hybridisation with synthetic fibre. A comprehensive review conducted by Ibrahim et al. [32], Madhusudhan and Keerthi [33] and Jawaid and Khalil [34] on hybrid composite has confirming that thermal properties of natural and synthetic fibre hybrid composites are better than those of the non-hybrid composite due to the higher thermal stability of synthetic fibres. Atiqah et al. [35] also found that the addition of glass fibre in sugar palm fibre reinforced with polyurethane showed better thermal properties by improved in thermogravimetric analysis (TGA) and dynamic mechanical analysis (DMA). A thermal properties of glass fibre hybridisation with sisal fibre reinforced polypropylene composites were carried out by Jarukumjorn and Suppakarn [36] showed an improvement with addition of glass fibre. Thermal properties of sisal/glass hybrid polypropylene investigated by Nayak and Mohanty [37] observed in higher thermal stability in the hybrid composite. In addition, Nayak et al. [38] noticed that better thermal stability of the matrix polymer was obtained with the addition of bamboo and glass fibres, due to the hybridisation when using differential scanning calorimeter (DSC) and TGA.

In this study, investigation was carried out to study the thermal properties with the incorporation of woven kenaf and carbon fibre reinforced epoxy composite. The effect of carbon fibre on the thermal properties of woven kenaf reinforced epoxy composite was also observed. TGA and DSC were used to evaluate the thermal properties of the hybrid composite. Thermogravimetry was used to observe the thermal stability and degradation, while DSC was used to analyse the transition's temperature.

\section{Materials and Methods}

\subsection{Materials}

Epoxy resin was used as the polymer matrix and was supplied by Chemrex Corporation Sdn. Bhd. The woven kenaf was prepared manually using a hand loom. Carbon fibre was supplied by Spinteks Tekstil Ins. The properties of these material and the woven kenaf/carbon fibre hybrid composite fabrication comprehensively covered by Aisyah et al. [39]. In this study all types of composites: $100 \%$ carbon fibre and woven kenaf/carbon fibre hybrid composite were tested for their thermal properties. TGA and DSC analysis were carried out to further investigate the thermal properties of hybrid woven composites after the incorporation with carbon fibre. 


\subsection{Thermogravemetric analysis (TGA)}

TGA was measured using a thermogravimetric analyser (TGA Q500 from TA Instruments) to observe changes in temperature and time in the controlled environment. The samples were heated from 25 to 800 ${ }^{\circ} \mathrm{C}$ at a heating rate of $10{ }^{\circ} \mathrm{C} / \mathrm{min}$ in nitrogen gas flow rate of $50 \mathrm{~mL} / \mathrm{min}$. A sample of $8-10 \mathrm{mg}$ of the materials was heated in the sample pan and the recorded data were displayed as TG (weight loss as a function of temperature) and as DTG (derivative thermogravimetric, weight loss rate as a function of temperature).

\subsection{Differential Scanning Calorimeter (DSC)}

DSC analysis was carried out to identify the melting point and the highest temperature limit of the composites using a DSC Q20 from TA Instruments. The samples were heated at a rate of $10{ }^{\circ} \mathrm{C} / \mathrm{min}$ from 25-350 ${ }^{\circ} \mathrm{C}$ under nitrogen air. Nitrogen was used for efficient heat transfer and removal of volatiles from the sample. Each fibre sample was analysed separately and overlapped for comparison.

\section{Results and Discussion}

In order to study the effect of hybridisation of carbon fibre on the thermal stability of woven kenaf composites, TGA was conducted. The TG and DTG curves were used to obtain the onset of decomposition temperature $\left(\mathrm{T}_{\mathrm{on}}\right)$, temperature at the decomposition peak $\left(\mathrm{T}_{\mathrm{max}}\right)$, weight loss, and the fraction of material that is not volatile at $800{ }^{\circ} \mathrm{C}$, denoted as residual. Meanwhile, DSC was used to characterise transitions, for instance, crystallisation and melting, with the function of fabric design and fabric density of woven kenaf in the woven kenaf/carbon fibre hybrid composite.

\subsection{Thermogravimetric analysis (TGA) Analysis of Composites}

The TG and DTG curves of the composite is represented in Figures 1 and 2, respectively. The Ton, $\mathrm{T}_{\max }$, weight loss, and residual at $800{ }^{\circ} \mathrm{C}$ are tabulated in Table 1 . The weight loss percentage (Figure 1) shows there was a reduction in the weight loss as a function of temperature in the hybridisation of carbon fibre with woven kenaf,

The TG result of $100 \%$ carbon fibre in Figure 1 showed a single decomposition step with the highest Ton of $341^{\circ} \mathrm{C}$, compared to the woven kenaf/carbon fibre hybrid composite. From starting temperature of $25{ }^{\circ} \mathrm{C}$ to the temperature of $100{ }^{\circ} \mathrm{C}$, the composite lost only $0.53 \%$ of the initial weight that resembles to the evaporation of solvent materials. It can be observed that, at temperature range of $250-500{ }^{\circ} \mathrm{C}$, the recorded weight loss was about $37.38 \%$ due to the degradation and evaporation of carbon fibres and matrix. Then, the composite continued with a linear weight loss up to $800{ }^{\circ} \mathrm{C}$, where the final residue was $54.14 \%$, which indicated the total weight loss of only $44.25 \%$ from the initial weight. Also, only one main peak on the DTG curve (Figure 2) was observed corresponding to an apparent step of decomposition. The decomposition of carbon fibre epoxy composite around $300-500{ }^{\circ} \mathrm{C}$ was associated to the decomposition of an organic-based sizing compound on the carbon fibre $[40,41]$. In addition, the thermal properties of carbon fibre composite and their hybrid was studied by Dhakal et al. [42], found that the carbon fibre composite have higher Ton compared to those of the hybridisation with flax fibre, i.e., $365^{\circ} \mathrm{C}$. 
It was observed that the thermal degradation for all hybrid composites show a three steps of degradation processes, with a small noticeable step observed at the temperature below $100{ }^{\circ} \mathrm{C}$, due to the evaporation of water molecules in the kenaf fibre. From the TG and DTG curves, the small step of weight loss at the temperature range of $30-100{ }^{\circ} \mathrm{C}$ only found in the hybrid composites, which represents the release of moisture content, due to the water evaporation as the presence of water in lignocellulosic fibres $[42,43]$. On the other hand, the pure carbon fibre composites did not show weight loss at $100{ }^{\circ} \mathrm{C}$ temperature, which shows the absence of water molecule.

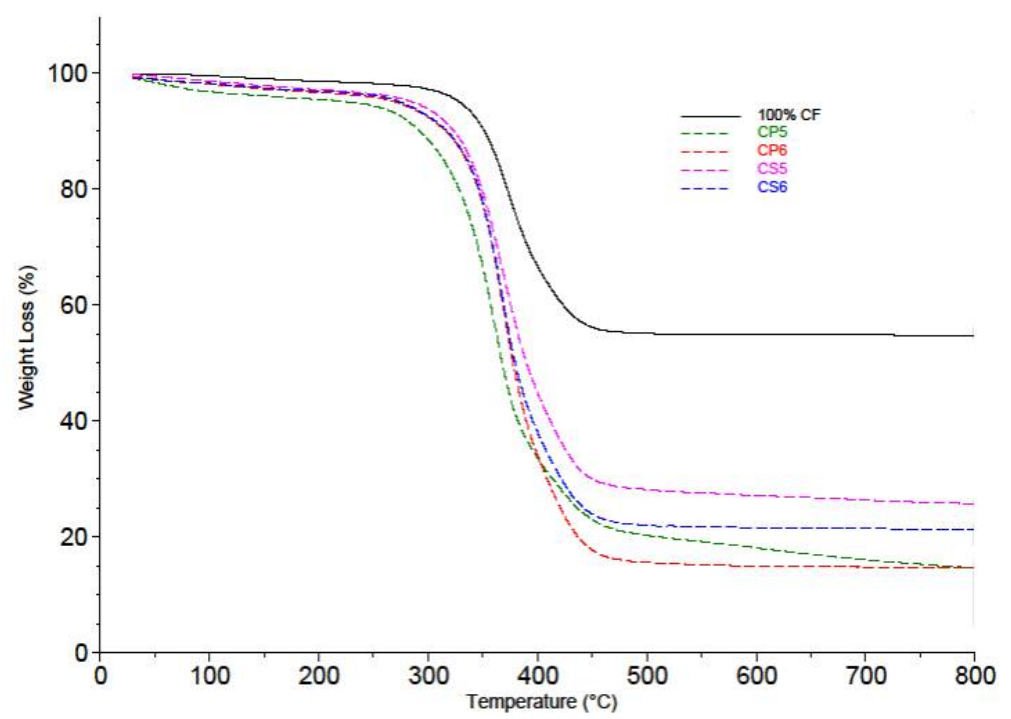

Figure 1. TGA curve on the effect of hybridization of woven kenaf in kenaf/carbon fibre hybrid woven composite on thermal properties.

Second step was corresponded to the weight loss of kenaf fibre, where a major decomposition occurred at a temperature range of $270-380{ }^{\circ} \mathrm{C}$. This was due to the decomposition of hemicellulose, cellulose, and lignin of natural fibres [44] and depolymerisation of the matrix [45]. The decomposition of natural fibres starts with hemicellulose, followed by cellulose, lignin, and ash. The hemicellulose starts to decompose early, normally at temperature of $220^{\circ} \mathrm{C}$ due to its chemical structure that consists of random amorphous structure with little strength, thus easily hydrolysed. In contrast, the decomposition of cellulose takes place at higher temperature $\left(315-390^{\circ} \mathrm{C}\right)$ than those of the hemicellulose because of its long polymer of glucose units and high crystalline nature, thus cellulose is relatively thermally stable [46]. The third degradation step is around $370-420{ }^{\circ} \mathrm{C}$, which related to the degradation of carbon fibre chain rupture, where styrene was the primary product [47]. 


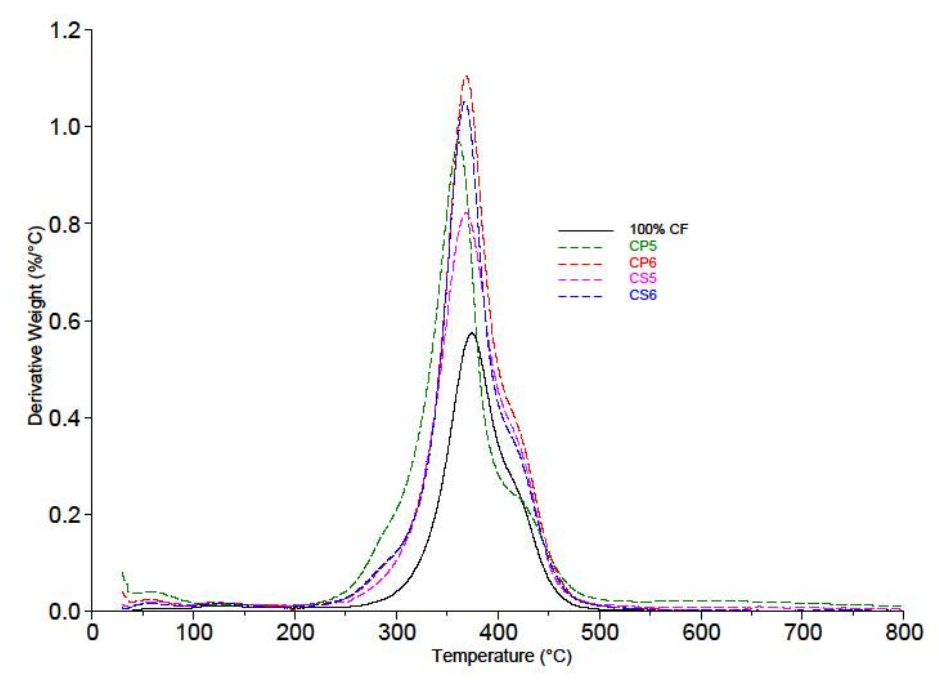

Figure 2. DTG curve on the effect of hybridization of woven kenaf in kenaf/carbon fibre hybrid woven composite on thermal properties.

From Table 1, the Ton of $100 \%$ carbon fibre was $341.41{ }^{\circ} \mathrm{C}$, and the $\mathrm{T}$ on of hybrid composites were around $331.27-336.11^{\circ} \mathrm{C}$. The incorporation of woven kenaf into carbon fibre composites decreased the Ton of neat carbon fibre because some portion of the synthetic fibre is replaced with less thermally stable material, i.e., kenaf fibres. Based on the TG curves, composite with woven kenaf with plain fabric (CP5 and CP6) show a move in the decomposition process towards a higher temperature level at $364-368{ }^{\circ} \mathrm{C}$. The remarkable increase in thermal stability upon the weave design in the composite structure also can be related to the fibre and fibre interaction. It can be concluded that another factor that contributes to the higher thermal stability of polymeric composites is the better interaction between fibre and the matrix, which resulted in additional intermolecular bonding between fibre and matrix [48]. This can be support by the high tensile and impact properties of the plain composite in previous study [39].

Table 1 : Characteristic temperature at elevated weight loss

\begin{tabular}{ccccc}
\hline Sample Type & T $_{\text {on }}\left({ }^{\circ} \mathrm{C}\right)$ & $\mathrm{T}_{\max }\left({ }^{\circ} \mathrm{C}\right)$ & $\begin{array}{c}\text { Weight Loss } \\
\text { (wt.\%) }\end{array}$ & $\begin{array}{c}\text { Residue at } \mathbf{8 0 0} \\
\text { (wt.\%) }\end{array}$ \\
\hline 100\% CF & 341.41 & 381.34 & 44.25 & 54.14 \\
CP5 & 331.27 & 363.58 & 81.90 & 13.09 \\
CP6 & 336.11 & 368.91 & 82.04 & 14.44 \\
CS5 & 331.62 & 364.13 & 71.97 & 20.92 \\
CS6 & 334.88 & 368.02 & 75.89 & 20.79 \\
\hline
\end{tabular}

Notes : CF $=$ Carbon Fibre Composite, CP5 $=$ Hybrid Plain Kenaf Composite $(5 \times 5$ fabric count $)$ with CF; CP6 $=$ Hybrid Plain Kenaf Composite $(6 \times 6$ fabric count $)$ with CF; CS5 $=$ Hybrid Satin Kenaf Composite $(5 \times 5$ fabric count) with CF; CS5 $=$ Hybrid Satin Kenaf Composite $(6 \times 6$ fabric count) with $\mathrm{CF}$

It is notable that, the $\mathrm{T}_{\max }$ of hybrid composite increased from $363.58-368.91{ }^{\circ} \mathrm{C}$ and $364.13-368.02$ ${ }^{\circ} \mathrm{C}$ by increasing the fabric density of woven kenaf from $5 \times 5$ to $6 \times 6$ in the plain and satin fabrics, respectively. The increase in $T_{\max }$ could be associated with the amount of cellulosic content in kenaf fibre which increased by increasing the fabric density, indicating that the kenaf fibre is able to improve the 
thermal stability of woven kenaf/carbon fibre hybrid composite. This is in agreement with a study conducted by Atiqah et al. [35], who found that higher sugar palm fibre loading resulted in more thermally stable sugar palm/glass fibre polyurethane composite. As depicted in Figure 2, the DTG curve for $6 \times 6$ of fabric density (CP6 and CS6) was shifted to higher temperatures with the increasing amount of kenaf fibre. This phenomenon might be due to the higher amount of hydrogen bonds between cellulose chains in the 6 $\times 6$ composites that can lead to more ordered and packed cellulose regions. This may further increase the thermal decomposition temperature of cellulose [49]. In addition, Nair et al. [48] mentioned that more ordered region decreases the mobility of cellulose chains will strain and weaken the existing hydrogen bonding thus increasing the thermal stability of composite.

From the result shown in Table 1, the highest final residue at $800{ }^{\circ} \mathrm{C}$ was observed in $100 \%$ carbon fibre composite (54.14\%), while the lowest residue was found in woven kenaf with plain fabric (CP5 and CP6). This is attributed to the resistance of carbon fibre to high temperature and better fibre matrix compatibility. The satin fabric hybrid composites (CS5 and CS6) showed residual of nearly $21 \%$. Conversely, the residual left at $800{ }^{\circ} \mathrm{C}$ for both plain fabric hybrid composites decreased significantly to approximately $13 \%$ and $14 \%$, respectively. This was probably due to the resin-rich area found in the satin composite [39]. At the first stage, the hemicellulose, cellulose, and lignin in kenaf fibres were decomposed and formed charred layers that could prevent further degradation on the polymer matrix. According to Asim et al. [45], at higher temperature $\left(30{ }^{\circ} \mathrm{C}\right.$ and above), epoxy starts to decompose. As the satin fabric contains more epoxy that are not infused into the inter-yarn due to the fabric structure [39], it resulted in more residual and forms a thicker layer between the heat source and polymeric material. This thicker layer residual results in the higher temperatures required for the composites decomposition and caused higher in residual content [50].

\subsection{Differential scanning calorimetric (DSC) Analysis of Composites}

The DSC analysis was carried out to further investigate the thermal behavior of hybrid composites after the incorporation with woven kenaf at the core layer of reinforced epoxy laminate composites composite. Figure 3 shows the DSC curves of hybrid composites containing CP5 (composite with plain fabric and $5 \times 5$ fabric count), CP6 (composite with plain fabric and $6 \times 6$ fabric count), CS5 (composite with satin fabric and $5 \times 5$ fabric count), CS6 (composite with satin fabric and $6 \times 6$ fabric count) and $100 \% \mathrm{CF}$ (composite with pure carbon fibre). The curves obtained for the composite are showing an exothermic and endothermic behaviour, indicating the melting and crystallisation of composite samples. The thermal parameters of melting and crystallisation of the samples are summarised in Table 2.

From Figure 3, the addition of woven kenaf into carbon fibre hybrid composites affected the thermal behaviour significantly. It is clearly shown that the heat released from $100 \%$ CF composite was higher than that of the hybrid composite. From the curves, the curing temperature $\left(T_{c}\right)$ and melting temperatures $\left(\mathrm{T}_{\mathrm{m}}\right)$ values of the composites were strongly influenced by the incorporation of woven kenaf in the matrix polymer. The $\mathrm{T}_{\mathrm{m}}$ of plain-designed hybrid composites and satin-designed hybrid composites decreased compared to the $\mathrm{T}_{\mathrm{m}}$ of pure carbon fibre composite. This is probably due to the incorporation of woven kenaf reduces the total energy needed to be absorbed to break up the polymer chains of composites. 


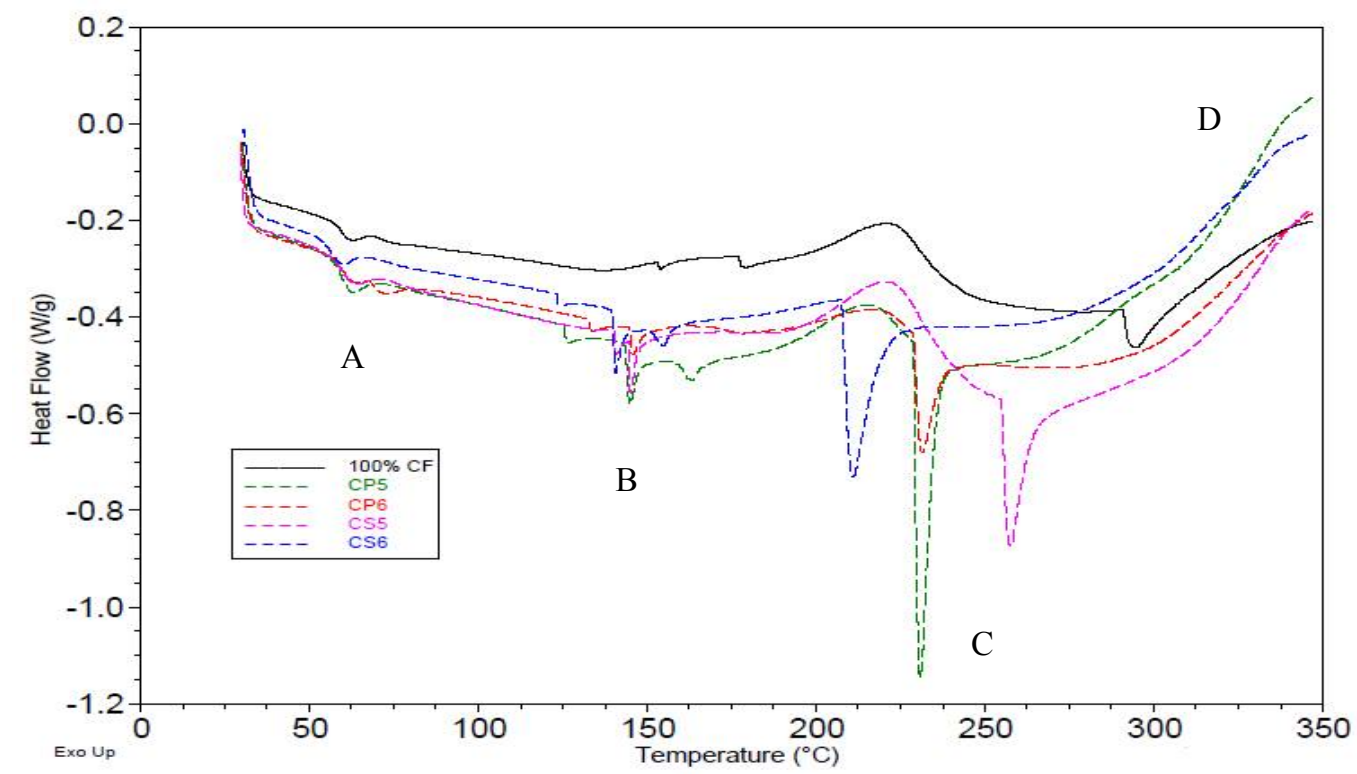

Figure 3. Thermal transitions DSC of the woven kenaf/carbon fibre hybrid composite vs. $100 \%$ carbon fibre epoxy composite.

The first drop of curvature was at around $58{ }^{\circ} \mathrm{C}$ (point A), displayed the glass transition temperature $(\mathrm{Tg})$, indicated as the starting point for the energy required to change the molecular structure inside the composites from a low energy state i.e., solid or glassy state, to a higher energy state i.e., rubbery state. The thermal decomposition continued until a temperature of $122{ }^{\circ} \mathrm{C}$ (point $\mathrm{B}$ ), and it is observed that there were multiple peaks for hybrid composites sample, but in the carbon fibre composite only two small peaks appeared. At this point, chains in the polymer might start to change the molecular structure to decompose from amorphous solid to crystalline solid by partially arranging their structures. As can be observed, the peak shifts to higher temperatures with the increase in the woven kenaf content (fabric count of $6 \times 6$ ). This finding is in line with a study conducted by Mofokeng et al. [51], who found that, as the fibre content of sisal fibre in poly(lactic acid) (PLA) and polypropylene (PP) composites increase, the crystallisation peak intensity decreased and it shifted to higher temperatures. They concluded that the sisal fibres act as the nucleation sites for the crystallisation of polymer, thus it restricts the mobility of the polymer chains. These sites may be particulates or fibres dispersed in the matrix, thus small crystals were formed around them [52]. In addition, kenaf fibres mainly consists of cellulose that represents the crystalline part of the materials, which could also result in increased crystallinity of the composites.

Table 2 : DSC results ofpure carbon fibre and woven kenaf/carbon fibre hybrid composites

\begin{tabular}{ccc}
\hline Sample Type & $\mathbf{T}_{\mathbf{c}}\left({ }^{\circ} \mathbf{C}\right)$ & $\mathbf{T}_{\mathbf{m}}\left({ }^{\circ} \mathbf{C}\right)$ \\
\hline $\mathbf{1 0 0} \%$ CF & 178.2 & 294.4 \\
CP5 & 145.0 & 257.4 \\
CP6 & 140.6 & 211.4 \\
CS5 & 145.9 & 231.3 \\
CS6 & 144.7 & 230.7 \\
\hline
\end{tabular}

Notes : $\mathrm{CF}=$ Carbon Fibre Composite, $\mathrm{CP} 5=$ Hybrid Plain Kenaf Composite $(5 \times 5$ fabric count $)$ with CF; CP6 $=$ Hybrid Plain Kenaf Composite $(6 \times 6$ fabric count $)$ with CF; CS5 $=$ Hybrid Satin 
Kenaf Composite $(5 \times 5$ fabric count) with CF; CS5 $=$ Hybrid Satin Kenaf Composite $(6 \times 6$ fabric count) with CF.

Subsequently, there were very strong endothermic peaks for all hybrid composite known as $\mathrm{T}_{\mathrm{m}}$. At the temperature range of $211-261{ }^{\circ} \mathrm{C}$ (point C), there were endothermic peaks for hybrid composite samples, identified as thermal degradation due to the hemicellulose and cellulose degraded in kenaf fibres. It was reported that, chemical constituents in natural fibres starts degrading at a temperature around 200 ${ }^{\circ} \mathrm{C}[53,54]$. This peak is attributed to the dehydration, by splitting of hydroxyl groups of the cellulose molecule, resulting in the formation of water molecules and depolymerisation of cellulose, leading to the formation of flammable volatile products. The peak intensity of the $\mathrm{T}_{\mathrm{m}}$ increased in the presence of higher kenaf fibre content (woven fabric of $6 \times 6$ ) probably due to more heat required to be absorbed to break up the polymer chains in composites. Additionally, hybrid composite with woven fabric of $5 \times 5$ showed better bonding properties between woven kenaf and carbon fibre with the matrix, thus crystallising at higher temperatures. For $100 \%$ carbon fibre, it can also be observed that the heat required to generate these peaks were higher than the hybrid samples $\left(293^{\circ} \mathrm{C}\right)$ indicating that this melting temperature of carbon fibre is contributed to the crystalline structure in carbon fibre through evaporation of the solvent during heating [55]. It is notably that the hybrid samples showed higher exothermic peak (point D) than the pure carbon fibre composite samples, indicating that the degradation of lignin and cellulosic matters from the kenaf fibres as lignin start to decompose at temperature of $340^{\circ} \mathrm{C}$ and above $[54,56]$. Thus, it can be stated that, the hybridisation of woven kenaf with carbon fibre in the composite structure become more thermally stable. The decomposition in $100 \%$ CF is probably due to the decomposition mechanism of epoxy resins through cyclisation of aliphatic chain ends [57].

\section{Conclusions}

The effects of hybridisation of carbon fibre with woven kenaf composites on thermal stability were examined. Although TG and DTG curves revealed that the thermal stability of carbon fibre composite was higher than that of the hybrid composite, the thermal stability of the hybrid composites improved upon the high content of kenaf fibre by using fabric density of $6 \times 6$. It was found that using the plain weave design of woven kenaf has improved the thermal stability than the satin design. The addition of carbon fibre in woven kenaf hybrid composites has improved the TGA properties of hybrid composites. The DSC results shows that the plain weave design and fabric count of $5 \times 5$ owned better interfacial adhesion between fibre and matrix. Thus, the hybrid composites are suitable for various applications that require at elevated temperatures. The DSC results discovered that the hybrid composite is more stable due to high decomposition temperature.

Funding: This research was funded by Aerospace Malaysia Innovation Centre (AMIC) and Higher Education Center of Excellence (HICoE), Ministry of Higher Education, Malaysia (Grant number 9300426 and 6369109 respectively).

\section{References}

1. Ibrahim, Z.; Ahmad, M.; Aziz, A.A.; Ramli, R.; Jamaludin, M.A.; Muhammed, S.; Alias, A.H. (2016). Dimensional stability properties of medium density fibreboard (MDF) from treated oil palm (Elaeis guineensis) empty fruit bunches (EFB) fibres. Open Journal of Composite Materials 2016, 6(04), 91. doi: 10.4236/ojcm.2016.64009 
2. Fatima, S.; Mohanty, A.R. Acoustical and fire-retardant properties of jute composite materials. Applied acoustics 2011, 72(2-3), 108-114. doi: 10.1016/j.apacoust.2010.10.005

3. Liu, L.; Yu, J.; Cheng, L.; Yang, X. Biodegradability of poly (butylene succinate)(PBS) composite reinforced with jute fibre. Polymer Degradation and Stability 2009, 94(1), 90-94. doi: 10.1016/j.polymdegradstab.2008.10.013

4. Goutianos, S.; Peijs, T.; Nystrom, B.; Skrifvars, M. Development of flax fibre based textile reinforcements for composite applications. Applied Composite Materials 2006, 13(4), 199-215. doi: 10.1007/s10443-006-9010-2

5. Hanafee, Z.M.; Khalina, A.; Norkhairunnisa, M.; Syams, Z.E.; Liew, K.E. The effect of different fibre volume fraction on mechanical properties of banana/pineapple leaf (PaLF)/glass hybrid composite. In 3rd Electronic And Green Materials International Conference 2017, Krabi, Thailand, 29-30 April 2017; Mohd. Mustafa Albakri Abdullah, Muhammad Mahyiddin Ramli, Shayfull Zamree Abd Rahim, Siti Salwa Mat Isa, Mohd Nasir Mat Saad, Rizalafande Che Ismail and Mohd Fathullah Ghazli; AIP Publishing: USA, 2017; Vol1885, No. 1, p. 020145)..

6. Anuar, H.; Zuraida, A. Improvement in mechanical properties of reinforced thermoplastic elastomer composite with kenaf bast fibre. Composites Part B: Engineering 2011, 42(3), 462-465. doi: 10.1016/j.compositesb.2010.12.013

7. Aisyah, H.A.; Paridah, M.T.; Sahri, M.H.; Anwar, U.M.K.; Astimar, A.A. Properties of medium density fibreboard (MDF) from kenaf (Hibiscus cannabinus L.) core as function of refining conditions. Composites Part B: Engineering 2013, 44(1), 592-596. doi: 10.1016/j.compositesb.2012.02.029

8. Lodha, P.; Netravali, A.N. Characterization of interfacial and mechanical properties of "green" composites with soy protein isolate and ramie fiber. Journal of Materials Science 2002, 37(17), 3657-3665. doi: 10.1023/A:1016557124372

9. Haque, M.M.; Hasan, M.; Islam, M.S.; Ali, M.E. Physico-mechanical properties of chemically treated palm and coir fiber reinforced polypropylene composites. Bioresource Technology 2009, 100(20), 49034906. doi: 10.1016/j.biortech.2009.04.072

10. Ashori, A. Wood-plastic composites as promising green-composites for automotive industries!. Bioresource Technology 2008, 99(11), 4661-4667. doi: 10.1016/j.biortech.2007.09.043

11. Paridah, M.T.; Basher, A.B.; SaifulAzry, S.; Ahmed, Z. Retting process of some bast plant fibres and its effect on fibre quality: A review. BioResources 2011, 6(4), 5260-5281. doi: 10.15376/biores.6.4.52605281

12. Ahmad, A.M.; Jalaluddin, H.; Paridah, M.T.; Resalati, H.; Rushdan, I.; Shamsi, S.R.F.; Ainun, Z.M. A review of literatures related of using kenaf for pulp production (beating, fractionation, and recycled fiber). Modern Applied Science 2010, 4(9), 21-29.

13. Aji, I.S.; Sapuan, S.M.; Zainudin, E.S.; Abdan, K. Kenaf fibres as reinforcement for polymeric composites: A review. International Journal of Mechanical and Materials Engineering 2009, 4(3), 239-248.

14. Juliana, A.H.; Aisyah, H.A.; Paridah, M.T.; Adrian, C.C.Y.; Lee, S.H. kenaf fiber: structure and properties. In Kenaf Fibers and Composites, 1st ed.; Sapuan, S.M.; Ishak, J.R.; Sahari, J.; Sanyang, M.L.; CRC Press: Boca Rotan, USA, 2018; pp. 23-36. doi: 10.1201/9781351050944

15. Nishino, T.; Hirao, K.; Kotera, M.; Nakamae, K.; Inagaki, H. Kenaf reinforced biodegradable composite. Composites Science ETechnology 2003, 63(9),1281-1286. doi: 10.1016/S0266-3538(03)00099-X

16. Khalil, H.A.; Yusra, A.I.; Bhat, A.H.; Jawaid, M. Cell wall ultrastructure, anatomy, lignin distribution, and chemical composition of Malaysian cultivated kenaf fiber. Industrial Crops and Products 2010, 31(1), 113-121. doi: 10.1016/j.indcrop.2009.09.008

17. Ashori, A.; Harun, J.; Raverty, W.D.; Yusoff, M.N.M. Chemical and morphological characteristics of Malaysian cultivated kenaf (Hibiscus cannabinus) fiber. Polymer-Plastics Technology and Engineering 2006, 45(1), 131-134. doi: 10.1080/03602550500373782 
18. Ververis, C.; Georghiou, K.; Christodoulakis, N.; Santas, P.; Santas, R. Fiber dimensions, lignin and cellulose content of various plant materials and their suitability for paper production. Industrial crops and products 2004, 19(3), 245-254. doi: 10.1016/j.indcrop.2003.10.006

19. El-Shekeil, Y.A.; Sapuan, S.M.; Jawaid, M.; Al-Shuja'a, O.M. Influence of fiber content on mechanical, morphological and thermal properties of kenaf fibers reinforced poly (vinyl chloride)/thermoplastic polyurethane poly-blend composites. Materials \& Design 2014, 58, 130-135. doi: 10.1016/j.matdes.2014.01.047

20. Bax, B.; Müssig, J. Impact and tensile properties of PLA/Cordenka and PLA/flax composites. Composites Science and Technology 2008, 68(7-8), 1601-1607. doi: 10.1016/j.compscitech.2008.01.004

21. Petroudy, S.D. Physical and mechanical properties of natural fibers. In Advanced High Strength Natural Fibre Composites in Construction, Mizi F., Feng F.; Woodhead Publishing, Cambridge, England, 2017; pp. 59-83. doi: 10.1016/C2014-0-03942-1

22. Mwaikambo, L.Y.; Ansell, M.P. Chemical modification of hemp, sisal, jute, and kapok fibers by alkalization. Journal of Applied Polymer Science 2002, 84(12), 2222-2234. doi: 10.1002/app.10460

23. Paridah, M.T.; Juliana, A.H. Adhesion Characteristics of Kenaf Fibers. In Kenaf Fibers and Composites, 1st ed.; Sapuan, S.M.; Ishak, J.R.; Sahari, J.; Sanyang, M.L.; CRC Press: Boca Rotan, USA, 2018; pp. 3760. doi: 10.1201/9781351050944

24. Aisyah, H.A.; Paridah, M.T.; Sahri, M.H.; Astimar, A.A.; Anwar, U.M.K. Influence of thermo mechanical pulping production parameters on properties of medium density fibreboard made from kenaf bast. Journal of Applied Sciences 2012, 12(6), 575-580. doi: 10.3923/jas.2012.575.580

25. Araujo, J.R.; Waldman, W.R.; De Paoli, M.A. Thermal properties of high density polyethylene composites with natural fibres: Coupling agent effect. Polymer Degradation and Stability 2008, 93(10), 1770-1775. doi:10.1016/j.polymdegradstab.2008.07.021

26. Yahaya, R.; Sapuan, S.M.; Jawaid, M.; Leman, Z.; Zainudin, E.S. Mechanical performance of woven kenaf-Kevlar hybrid composites. Journal of Reinforced Plastics and Composites 2014, 33(24), 2242-2254. doi: $10.1177 / 0731684414559864$

27. Zhang, Y.; Li, Y.; Ma, H.; Yu, T. Tensile and interfacial properties of unidirectional flax/glass fiber reinforced hybrid composites. Composites Science and Technology 2013, 88, 172-177. doi: 10.1016/j.compscitech.2013.08.037

28. Niedermann, P.; Szebényi, G.; Toldy, A. Characterization of high glass transition temperature sugarbased epoxy resin composites with jute and carbon fibre reinforcement. Composites Science and Technology 2015, 117, 62-68. 10.1016/j.compscitech.2015.06.001

29. Khanam, P.N.; Khalil, H.A.; Jawaid, M.; Reddy, G.R.; Narayana, C.S.; Naidu, S.V. Sisal/carbon fibre reinforced hybrid composites: tensile, flexural and chemical resistance properties. Journal of Polymers and the Environment 2010, 18(4), 727-733. doi: 10.1007/s10924-010-0210-3

30. Romanzini, D.; Lavoratti, A.; Ornaghi Jr, H.L.; Amico, S.C.; Zattera, A.J. Influence of fiber content on the mechanical and dynamic mechanical properties of glass/ramie polymer composites. Materials $\mathcal{E}$ Design 2013, 47, 9-15. 10.1016/j.matdes.2012.12.029

31. Dhakal, H.N.; Zhang, Z.Y.; Guthrie, R.; MacMullen, J.; Bennett, N. Development of flax/carbon fibre hybrid composites for enhanced properties. Carbohydrate Polymers 2013, 96(1), 1-8. doi: 10.1016/j.carbpol.2013.03.074

32. Ibrahim, I.D.; Sadiku, E.R.; Jamiru, T.; Kupolati, W.K.; Agwuncha, S.C.; Fasiku, V.O.; Khoathane, M.C.; Mhike, W.; Dludlu, M.K.; Avabaram, B.R.; Bandla, M. Hybrid Natural/Synthetic Fibre. In Biocomposites: Properties, Performance and Applications. Asim Shahzad; Nova Science Publishers, USA, 2017, pp.27.

33. Madhusudhan, T.; Keerthi Swaroop, G. A review on mechanical properties of natural fiber reinforced hybrid composites. International Research Journal of Engineering and Technology (IRJET) 2016, 2395-0056. 
34. Jawaid, M.; Khalil, H.P.S.A. Cellulosic/synthetic fibre reinforced polymer hybrid composites: A review. Carbohydrate Polymers 2011, 86(1), 1-18. doi: 10.1016/j.carbpol.2011.04.043

35. Atiqah, A.; Jawaid, M.; Sapuan, S.M.; Ishak, M.R.; Alothman, O.Y. Thermal properties of sugar palm/glass fiber reinforced thermoplastic polyurethane hybrid composites. Composite Structures 2018, 202, 954-958. doi: 10.1016/j.compstruct.2018.05.009

36. Jarukumjorn, K.; Suppakarn, N. Effect of glass fiber hybridization on properties of sisal fiberpolypropylene composites. Composites Part B: Engineering 2009, 40(7), 623-627. doi: 10.1016/j.compositesb.2009.04.007

37. Nayak, S.K.; Mohanty, S. Sisal glass fiber reinforced PP hybrid composites: Effect of MAPP on the dynamic mechanical and thermal properties. Journal of Reinforced Plastics and Composites 2010, 29(10), 1551-1568. doi: 10.1177/0731684409337632

38. Nayak, S.K.; Mohanty, S.; Samal, S.K. Influence of short bamboo/glass fiber on the thermal, dynamic mechanical and rheological properties of polypropylene hybrid composites. Materials Science and Engineering: A 2009, 523(1-2), 32-38. doi : 10.1016/j.msea.2009.06.020

39. Aisyah, H.A.; Paridah, M.T.; Khalina, A.; Sapuan, S.M.; Wahab, M.S.; Berkalp, O.B.; Lee, C.H.; Lee, S. $\mathrm{H}$. Effects of fabric counts and weave designs on the properties of laminated woven kenaf/carbon fibre reinforced epoxy hybrid composites. Polymers 2018, 10(12), 1320. doi: 10.3390/polym10121320

40. Tranchard, P.; Duquesne, S.; Samyn, F.; Estebe, B.; Bourbigot, S. Kinetic analysis of the thermal decomposition of a carbon fibre-reinforced epoxy resin laminate. Journal of Analytical and Applied Pyrolysis 2017, 126, 14-21. doi: 10.1016/j.jaap.2017.07.002

41. Feih, S.; Mouritz, A. P. Tensile properties of carbon fibres and carbon fibre-polymer composites in fire. Composites Part A: Applied Science and Manufacturing 2012, 43(5), 765-772. doi: 10.1016/j.compositesa.2011.06.016

42. Dhakal, H.N.; Zhang, Z.Y.; Guthrie, R.; MacMullen, J.; Bennett, N.Development of flax/carbon fibre hybrid composites for enhanced properties. Carbohydrate Polymers 2013, 96(1), 1-8. doi: 10.1016/j.carbpol.2013.03.074

43. Sanyang, M.L.; Sapuan, S.M.; Jawaid, M.; Ishak, M.R.; Sahari, J. Effect of plasticizer type and concentration on tensile, thermal and barrier properties of biodegradable films based on sugar palm (Arenga pinnata) starch. Polymers 2015, 7(6), 1106-1124. doi: 10.3390/polym7061106

44. Kumar, S. S.; Duraibabu, D.; Subramanian, K. Studies on mechanical, thermal and dynamic mechanical properties of untreated (raw) and treated coconut sheath fiber reinforced epoxy composites. Materials \& Design 2014, 59, 63-69. doi: 10.1016/j.matdes.2014.02.013

45. Asim, M.; Jawaid, M.; Nasir, M.; Saba, N. Effect of fiber loadings and treatment on dynamic mechanical, thermal and flammability properties of pineapple leaf fiber and kenaf phenolic composites. Journal of Renewable Materials 2018, 6(4), 383-393. doi: 10.7569/JRM.2017.634162

46. Yang, H.; Yan, R.; Chen, H.; Zheng, C.; Lee, D.H.; Liang, D.T. In-depth investigation of biomass pyrolysis based on three major components: hemicellulose, cellulose and lignin. Energy \& Fuels 2006, 20(1), 388-393. doi: 10.1021/ef0580117

47. Manfredi, L.B.; Rodríguez, E.S.; Wladyka-Przybylak, M.; Vázquez, A. Thermal degradation and fire resistance of unsaturated polyester, modified acrylic resins and their composites with natural fibres. Polymer Degradation and Stability 2006, 91(2), 255-261. doi: 10.1016/j.polymdegradstab.2005.05.003

48. Nair, K.M.; Thomas, S., Groeninckx, G. Thermal and dynamic mechanical analysis of polystyrene composites reinforced with short sisal fibres. Composites Science and Technology 2001, 61(16), 2519-2529. doi: 10.1016/S0266-3538(01)00170-1

49. Poletto, M.; Pistor, V.; Zattera, A. J. Structural characteristics and thermal properties of native cellulose. In Cellulose-fundamental aspects. Theo G.M. Van De Ven; InTech Open, UK, 2013; pp. 45-68. doi: $10.5772 / 50452$ 
50. Norizan, M.N.; Abdan, K.; Salit, M.S.; Mohamed, R. Physical, mechanical and thermal properties of sugar palm yarn fibre loading on reinforced unsaturated polyester composites. Journal of Physical Science 2017, 28(3), 115-136. doi: 10.21315/jps2017.28.3.8

51. Mofokeng, J.P.; Luyt, A.S.; Tábi, T.; Kovács, J. Comparison of injection moulded, natural fibrereinforced composites with PP and PLA as matrices. Journal of Thermoplastic Composite Materials 2012, 25(8), 927-948. doi: 10.1177/0892705711423291

52. Gomes, T.S.; Visconte, L.L.; Pacheco, E.B. Mechanical and thermal behavior of composites based on high density polyethylene and banana tree fiber. Polímeros 2013, 23(2), 206-211. doi: 10.4322/S010414282013005000010

53. Sinha, E.; Rout, S.K. Influence of fibre-surface treatment on structural, thermal and mechanical properties of jute fibre and its composite. Bulletin of Materials Science 2009, 32(1), 65. doi: 10.1007/s12034-009-0010-3

54. Kabir, M.M.; Islam, M.; Wang, H. Mechanical and thermal properties of jute fibre reinforced composites. Journal of Multifunctional Composites 2013, 1(1). 71-77.

55. Hong, S.G.; Lin, Y.C.; Lin, C.H. Crystallization and degradation behaviors of treated polyhydroxybutyrates. Reactive and Functional Polymers 2008, 68(11), 1516-1523. doi: /10.1016/j.reactfunctpolym.2008.08.003

56. Sharma, R.K.; Wooten, J.B.; Baliga, V.L.; Lin, X.; Chan, W.G.; Hajaligol, M.R. Characterization of chars from pyrolysis of lignin. Fuel 2004, 83(11-12), 1469-1482. doi: 10.1016/j.fuel.2003.11.015

57. Levchik, S.V.; Weil, E.D. Thermal decomposition, combustion and flame-retardancy of epoxy resinsa review of the recent literature. Polymer International 2004, 53(12), 1901-1929. doi: 10.1002/pi.1473 